\title{
The Paradox of Transgressing Sexual Identities: Mapping the Micropolitics of Sexuality/Subjectivity in Ang Lee's Films
}

\author{
Che-ming Yang \\ Associate Professor \\ Department of Foreign Languages and Literature \\ National Cheng Kung University \\ E-mail: yang5692@mail.ncku.edu.tw
}

\begin{abstract}
From a perspective of multiculturalism, this paper aims to analyze Ang Lee's Wedding Banquet and Brokeback Mountain by elaborating on the issues of sex/gender/identity in the hope of exploring the process and problematics of cultural formations in the era of globalization characterized by multiculturalism. Based on Judith Buthler's deconstructive/postmodernist view of sex/gender/identity, the first part of this essay evaluates simultaneously both the positive and negative aspects of these two films; whereas Deleuze's literary aesthetics of minor literature offers me a subtle perspective on Ang Lee's extraordinary achievement in creating a minoritarian artistic work that exposes the complexity of human psyche/desire, which constitutes the second part of this essay. In addition, both parts intend to reexamine, from a perspective of multiculturalism, how Ang Lee's special micropolitics/aesthetics enables him to rewrite successfully Annie Proulx's short story for the screen so as to create a globally popular American love story that not only distinguishes him from the mediocre Hollywood commercial romance film makers but also simultaneously brings him fame and profit.
\end{abstract}

Keywords: Ang Lee, Globalization, Micropolitics, Deleuze, Desiring, Becoming, Deterritorialization, Gender, Sexuality, Identities

Becoming imperceptible is Life, "without cessation or condition" . . attaining to a cosmic and spiritual lapping.

—Gilles Deleuze

... the reality of gender is also put into crisis: it becomes unclear how to distinguish the real from the unreal. And this is the occasion in which we come to understand that what we take to be "real," what we invoke as the naturalized knowledge of gender is, in fact, a changeable and revisable reality. Call it subversive or call it something else. -Judith Butler

\section{Introduction}

This essay intends to adopt a perspective of multiculturalism by focusing on some films of Ang Lee, namely The Wedding Banquet and Brokeback Mountain, which elaborate on the issues of sex/gender/identity. To be more specific, the objective of this essay is no more than an attempt to (re)examine some contemporary means of representation (e.g. pop music, films, novels, TV programs) as manifested in Ang Lee's films of gender/identity in the hope of exploring the process and problematics of cultural formations in the era of globalization characterized by multiculturalism.

Taking his latest and award-winning film Brokeback Mountain for instance, Lee's (re)presentation of sexual identity in this film corresponds to Butler's major argument about the contingency and transgressivity of sexual desire/identities. Talking about what inspires the first part of this essay, Judith Buthler's deconstructive/postmodernist view of sex/gender/identity enables me to evaluate simultaneously both the positive and negative aspects of these two films; whereas Deleuze's literary aesthetics of minor literature offers me a subtle perspective on Ang Lee's extraordinary achievement in creating a minoritarian artistic work that exposes the complexity of human psyche/desire, which 
constitutes the second part of this essay. In addition, both parts intend to reexamine, from a perspective of multiculturalism, how Ang Lee's special micropolitics/aesthetics enables him to rewrite successfully Annie Proulx's short story for the screen so as to create a globally popular American love story that not only distinguishes him from the mediocre Hollywood commercial romance film makers but also simultaneously brings him fame and profit.

\section{Unmasking the Paradox of the Homosexual Subjects of Sex/Gender/Desire}

Corresponding to what Butler has indicated in the Preface 1999 to Gender Trouble, which highlights the contingency and ambiguity of her critique of gender issues,

I did not know that the text would have as wide an audience as it has had, nor did I know that it would constitute a provocative "intervention" in feminist theory or be cited as one of the founding texts of queer theory [my emphasis]. The life of the text has exceeded my intentions ... (vii)

this essay aims to employ her critique of gender issues to reveal the problematics of Ang Lee's representing the homosexual desiring production. In other words, her insight into the hegemony of phallogocentrism and heterosexuocentrism, both of which oppress the sexual minorities (respectively, women and homosexuals), happens to serve as a theoretical basis for my examination of Ang Lee's paradoxical nature of his micropolitics in representing the heterosexual/homosexual dualism.

In The Wedding Banquet (hereafter shortened as WB) as well as in Brokeback Mountain (hereafter shortened as BM), Ang Lee seems to have replicated the modes of heterosexual behaviors onto the gay couples. Viewed positively, Lee's (mis)representation of the gay sexuality by replicating the hegemonic heterosexual sexuality in presenting the love story of the gay couples could be considered as his strategy in rendering the homosexual sex/gender/identity acceptable to the "universal" audience, be they homosexuals or heterosexuals, through arousing their empathy toward the same-sex love. To be more specific, Lee seems to be intentionally blurring the distinction between heterosexuals and homosexuals and focusing the universal spectator's attention on the seemingly everlasting and sincere love between the gay couples. That is why in one of the interviews with Ang Lee, Lee argues that BM is not about homosexuality but about a love story.

Nevertheless, Lee's universal appeal by means of appropriating the modes of heterosexuality to present homosexuality happens to create a paradox in representing the sexual minorities - gay couples-in his films. As Irigaray's view on women sexuality has pointed out, "women constitute a paradox, if not a contradiction, within the discourse of identity itself. Women are the 'sex' which is not 'one.' Within a language pervasively masculinist, a phallogocentric language, women constitute the unrepresentable" (Butler, 1999: 14). Likewise, homosexuals (e.g. the gay couple in Lee's films) are also the unrepresentable subjects who are not "one" sex. The paradoxical nature of their relationships (the gay sexuality) also reveals a point of linguistic absence (Note 1). It is on one side same-sex desire, but on another, a mimesis of the mainstream heterosexual intercourse. Hence, Lee's projection of the heterosexual sexuality onto the same-sex relationships is no more than a simplification or stereotyping of human desire/gender/identity. Accordingly, Lee seems to represent the same-sex desire as something unpresentable.

As illustrated in WB, the gay couple-Wai-Tung (a Taiwanese who has a well-paying job, a nice home in New York) and Simon (an American) - are cast as a couple that live together as husband and wife who are in a good relationship, for the former plays the sex role of the masculine partner, whereas the latter the tender and considerate housewife, for Simon not only tenderly takes care of the former like a loving wife but also shows great talent for cooking. Furthermore, Simon's femininity is reinforced when "he" considerately presents his gift-some cosmetic product for elderly women - to Wei-Tung's mother. Moreover, his feminine/wifely role is approved by Wei-Tung's father, who finally accepts the fact that Simon is the real life partner of his son, not the fake daughter-in-law (Wei Wei), though she could bear him some grandchildren. Accordingly, Lee seems to be stereotyping an ideal homosexual relationship by replicating heterosexual mode of relationship onto this gay couple.

Viewed negatively, the heterosexual impulse is reinforced when this problematic comedy seems to compensate its evilness in its deceptive aspect by having Wei-Tung "accidentally" become "normal" and thus making Wei Wei conceived. The spectator may have a feeling that Lee seems to not only relieve same-sex love of its controversial nature - barrenness - but also add some glamour of humanity to it by presenting the gay couple's subjection to the heterosexual values and behaviors. The above-mentioned can be further illustrated by the closing scene in which the gay couple and the fake wife see off Wei-Tung's parents at the airport. Before they depart, they sit together as members of a harmonious family while gazing at the wedding photos.

Consequently, Lee seems to undercut the legitimacy of homosexuality and highlight its "weakness" by replicating the heterosexual values and behaviors onto the gay couple. Paradoxically enough, foregrounding the problems/deficiencies of same-sex desire/relationship by replicating the hegemonic heterosexual relationship onto the gay couple happens to relieve them of their "sin" (failure in filial piety) as well as show the gay couple one way out of their impasse, and simultaneously, bring them some glamour of humanity.

Likewise, the same paradoxical phenomena occur in BM, which focuses on the painstaking process of how the gay 
couple-Ennis and Jack - finally renounce/repress their perversion (same-sex desire) by marrying, respectively, a loving wife and henceforth having their own children. What is worth our attention is the fact that paradoxically and ironically, the ambivalence in Ennis's and Jack's desire happens to "elevate" the rarity of their camaraderie. In other words, same-sex desire is justified or "sanctified" by their inherent impulse toward heterosexual sexuality. Ennis, though haunted by the memory of his intimacy with Jack, still tries to maintain his courtship and marriage with his wife Alma, though later Alma abandons him and marries someone else after discovering his secret affair with Jack.

What is problematic is that Lee again seems to fall into the gender stereotype of masculine/feminine dualism in presenting the same-sex affair. Just as Butler's attack on sex/gender dualism (Man/Woman or masculine/feminine as One/Other) (Note 2), the binary discourse of masculine/feminine is inherent in Lee's BM when he has the gay couple replicating the man-woman roles in their sexual discourse (Ennis plays the sex role of man by sodomizing Jack in the shepherd's camp in Brokeback Mountain). This is a notion of a generally shared conception of "homosexual" relationships that intends to "misrepresent" same-sex love/intercourse in the heterosexual mode. Or we could interpret this phenomenon as representing the unrepresentable homosexuality in a heterosexuocentric language that results in a "linguistic absence and opacity," in which the homosexual "sex" is incomprehensible, just as Irigaray describes the feminine "sex" as "the impossibility of a grammatically denoted substance" (Gender Trouble 14-15). At the same time, it is a binary conception of gender/sex, as Butler rightly puts it:

If gender is the cultural meanings that the sexed body assumes, then a gender cannot be said to follow from a sex in any one way. Taken to its logical limit, the sex/gender distinction suggests a radical discontinuity between sexed bodies and culturally constructed genders. Assuming for the moment the stability of binary sex, it does not follow that the construction of "men will accrue exclusively to the bodies of males or that "women" will interpret only female bodies. ... The presumption of a binary gender system implicitly retains the belief in a mimetic relation of gender to sex whereby gender mirrors sex or is otherwise restricted. (1999: 10)

Therefore, Lee's conception of same-sex desire is oriented or imagined in a binary gender/sex discourse.

When it comes to the labyrinthine issues of sex/gender/identities, according to Judith Butler's "postmodernist" notion of (sexual) identity in Inside/Outside, all kinds of identities, including gender identities, are "a kind of impersonation and approximation" and even "a kind of imitation for which there is no original"; furthermore, identities are "constant switching among a range of different roles and positions, drawn form a kind of limitless data bank of potentialities" (Barry, 2002: 145). Therefore, Butler claims that there is no naturally-given normative selfhood and hence problematizes the distinction between sexual identities (i.e. heterosexuality as the "One" whereas homosexuality as the "Other"). Moreover, Butler's deconstructive view of identities subverts the binary One/Other pairing of sexual identity, because Butler claims that the "Other" is "as something within us as beyond us, and 'self' and 'Other' are always implicated in each other" (Barry, 2002: 145). In addition, Butler's approaches to identities are highly political and radical in that she argues that "identity can become a site of contest and revision." Those two films directed by Ang Lee happen to echo her critique of identities.

Given Butler's view of the ambivalence, hybridity, and contingency of gender/sex/identity, we may well say that in WB Wei-Tung's sexual identity and desire seem to echo Butler's argument about gender ambiguity when he temporarily "transforms" his homosexuality by having sex with Wei Wei on the wedding night and making her conceived. Besides, he could also pretend to be a "conventional" filially pious son by fulfilling his role-play at the wedding banquet. However, Wei-Tung soon regrets acting normal after he awakes from that heterosexual nightmare. He intends to have his fake wife undertake the abortion surgery. But later, his sense of maintaining his family lineage makes him decide to keep the embryo in Wei Wei's womb. In other words, under the great expectation of his traditional parents, Wei-Tung's sexual/gender identities are "constant switching among a range of different roles and positions, drawn from a kind of limitless data bank of potentialities" (Barry, 2002:145). Similarly, in BM, Ennis and Jack reveal the same "limitless" gender/sexual potentialities by marrying and having sex with their wives.

Though strongly attacking any universal claim in the issues of sex/gender/identity, Butler's view of the complexity of these issues happens to prove or imply the fact that the ambiguity of sex/gender/identity in human psyche is characteristic of humanity:

In the book [Gender Trouble], I tend to conceive of the claim of "universality" in exclusive negative and exclusionary terms. However, I came to see the term has important strategic use precisely as a non-substantial and open-ended category as I worked with an extraordinary group of activists . . . an organization that represents sexual minorities on a broad range of human rights issues. There I came to understand how the assertion of universality can be proleptic and performative, conjuring a reality that does not yet exist, and holding out the possibility for a convergence of cultural horizons that have not yet met. Thus, I arrived at a second view of universality [my emphasis] in which it is defined as a future-oriented labor of cultural translation [emphasis added]. (xvii)

Therefore, the "universality" as shown in human gender/sexual reality paradoxically results in a universal appeal in 
these two films of gender issues by Ang Lee. The film's great success may be attributed to its status as an important contemporary medium of mass entertainment, is mainly profit-oriented and commercialized for arousing empathy in the global audience that come to realize that they themselves, just like the gay couple in the two films, also have the same sexual/gender "potentialities."

Moreover, it proves that gender/sex is not a fixed state by nature as most people believe, when they accuse homosexuals of committing a sin by violating the natural law, as Connell puts it:

Being a man or a woman, then, is not a fixed state. It is a becoming [emphasis added], a condition actively under construction. . . . Psychological research suggests that the great majority of us combine masculine and feminine charatcteristics, in varying blends, rather than being all one or all the other. Gender ambiguity can be an object of fascination and desire, as well as disgust. (2004: 4-5)

To sum up, Lee's cinematic aesthetics is a special (re)writing of the mysteries of the becoming or process of deterritorialization of human psyche, which happens to echo one of Deleuze's major tenets of minor literature, which will be further elaborated in next section.

\section{A Schizoanalysis of the Minorization of Ang Lee's Micropolitics - Representing the Unrepresentable Homosexuals as Deterritorialized Subjects}

As mentioned above, in several of his films Ang Lee employs a special aesthetics/micropolitics in exploring the complexities and subtlety of human psyche and "desiring production" (a Deleuzian term). Consequently, I intend to revisit Ang Lee's films by adopting a Deleuzian perspective/micropolitics of (minor) literature, namely for Deleuze and Guattari, all great literature in a broader sense is minor literature, because it deconstructs and dislocates the long-established tradition and its "language seems foreign, open to mutation, and the vehicle for the creation of identity rather than the expression of identity" (Colebroook, 2002: 102-03).

Viewed from a Deleuzian perspective on minor writing/literature, Ang Lee's special micropolitics/aesthetics enables him to successfully rewrite Annie Proulx's short story for the screen so as to create a globally popular American love story. He creates a minoritarian writing that deviates from the majoritarian modes of representation in examining the complexity of human sex/gender/desire, and thus bridges the gap between literature and life, or reveals a Passage from the Literary/Fictional realm to real Life, as Deleuze maintains in the first chapter "Literature and Life" of Essays Critical and Clinical (Note 3):

Writing is a question of becoming, always incomplete, always in the midst of being formed, and goes beyond the matter of any livable or lived experience. It is a process, that is, a passage of Life that traverses both the livable and the lived. Writing is inseparable from becoming: in writing, one becomes-woman, becomes-animal or vegetable, becomes-molecule to the point of becoming-imperceptible. (Deleuze, 1997: 1)

Looking further into the underlying transforming forces in these two Ang Lee's films, the spectator could perceive a variety of minoritarian "becomings"/mutations, the process of liberating/deterritorializing a work of art, in Deleuzian terms, from the hierarchy or subjugation of a privileged/majoritarian mode of representation. Those becomings in those films are mainly "animal-becoming," "woman-becoming," and "imperceptible-becoming" that integrate the protagonists into some identities/gender other than their original ones, if any. In WB, Wei-Tung takes refuge in same-sex love as a way out of his father's great expectation - deterritorialization of the subjugation of heterosexuality. His becoming-gay does not renounce his deep-rooted sense of filial piety in continuing the family lineage by mating a "real" woman, which is against his gender/sexual "reality" at that moment. Paradoxically, even in the gay world, he plays the role of a masculine husband, which is appealing to the effeminate Simon and the real feminine figure-Wei Wei. In one word, Wei-Tung is becoming-imperceptible in an identity that is neither his "real" (original) nor a new one. Lee has made Wei-Tung "the vehicle for the creation of identity rather than the expression of identity" (Colebroook, 2002: 102-03).

Likewise, Ennis in BM demonstrates some complex identities that are similar to Wei-Tung's. The world Ennis and Jack live in is simultaneously transforming dramatically but yet barely evolving. They have to attach to the contemporary values - goals of life - such as getting a stable job, marrying and raising children of their own. It is hard to attribute their relationship to homosexuality. Rather, it is a lifelong spiritual and emotional connection, and an intimacy that is beyond their manipulation. We may well say that it is produced at some specific time and place but continues and develops as they can find no satisfactory spiritual fulfillments. Their platonic relationship can be testified by Ennis's refusal to accept the affection of a young woman after Jack dies in an accident. His love for Jack can be seen as the cherished memories of Brokeback Mountain, which lies deep in his psyche. He is becoming-Mountain - the source and goal of his psyche, just like Harry, the protagonist in one of Hemingway's well-known short stories "The Snows of Kilimanjaro," in which Harry shows great spiritual attachment to a mountain/peak that is a symbol of purity and escape. In other words, both Ennis and Jack take lines of flight or undertake a spiritual journey by becoming-mountain in consummating their love and pursuit of spiritual and emotional purgation. 
Besides, it is a desiring production of anyone who can hardly find a proper place/object or goal in life that could quench his thirst for Life. This "universality" claim may look especially appealing to those who have been trapped in the industrialized or commercialized cosmopolitan cities where sense of alienation prevails. In more specific Deleuzian terms, he is forming "lines of flight," a "deterritorialization" of this pragmatic and materialist world in which he finds no outlet for his desiring production. It is also a process of life in which "one has to lose his identity, one's face, in it. One has to disappear, to become unknown" (Dialogues 45). In fact, both Ennis and Jack undergo this process of Life-becoming imperceptible through becoming-Brokeback Mountain, the symbol of their goal in life. Their desire for each other originates there and the dream they share remains there-Brokeback Mountain has become the target where their souls and hearts dwell. Becoming-imperceptible or becoming-mountain opens up the two men to new possibilities of life. As a result, their identities are also changing, as Deleuze indicates:

To become is not to attain a form (identification, imitation, Mimesis) but to find the zone of proximity, indiscernibility, or indifferentiation where one can no longer be distinguished from $a$ woman, an animal, or $a$ molecule-neither imprecise nor general, but unforeseen and nonpreexistent, singularized out of a population rather than determined in a form. (Deleuze, 1997: 1)

Consequently, Ennis and Jack have become each other and this process is consummated in their camaraderie nurtured in/by the majestic Brokeback Mountain.

To be more specific, this process of becoming is the double becoming of the gay couple in which they undergo reciprocal becomings, or lines of flight (through their desiring production and being/becoming each other-a relationship that is deeper than love and higher than the "lived," as Daniel Smith observes, "a profound passion that traces a zone of indiscernibility between the two characters" (1997: xxxiii). Moreover, it is a process of "imperceptible-becoming," which makes a work of art, according to Deleuze, become a great work and thus renders itself open to intensities or possibilities of life, a constant process of deterritorialization. It also destroys the boundaries between the perceiver and the perceived. As a result, instead of placing the spectator in a "position of ordering judgement," the impulse toward minorization in those films enables the spectator to "become other through a confrontation with the forces that compose us" (Colebrook, 2002: 131). Consequently, even heterosexual or homophobic audience in the era of globalization could have a sense of empathy toward Ang Lee's films that deal with homosexuality through a micropolitics of gender/identity transgressivity.

When it comes to the minor writing or literature, in Deleuzian terms, that Ang Lee creates, Brokeback Mountain is a more typical case (though in a broader sense all great literature is minor literature), for it conforms to some main tenet of minor literature that Deleuze maintains:

4. The minorization of a major language (English) (Note 4) and sexuality (heterosexuality): Lee as a Taiwanese, educated in Mandarin Chinese but uses English to "write" an epic American love story. His universality lies in the empathy that he arouses in the western (or universal) audience by minorizing English the international/dominant language to depict the life story of how two men, despite the social convention that considers same-sex desire as a taboo, develop a lifelong or everlasting intimacy. On the one hand, the English-speaking characters and western setting bring about a more global audience. On the other hand, Lee's popularity lies in the strategies he employs in rendering the majoritarian language (English) seem foreign, "open to mutation"; and the film hence becomes "the vehicle for the creation of identity rather than the expression of identity" (Colebrook, 103-04). Or just like Deleuze's definition of a great author/artist that creates minor literature/writing:

The author, as subject of enunciation, is first of all a spirit: sometimes he identifies with his characters or makes us identify with them, or with the idea which they represent; sometimes on the other hand, he introduces a distance which allows him and us to observe, to criticize, to prolong. . . The author creates a world, but there is no world which awaits us to be created. . . One must, on the contrary, speak with, write with. With the world, with a part of the world, with people. (Deleuze and Parnet, 1977: 52)

In the case of BM, Lee creates a spiritual world-Brokeback Mountain - that is both appealing to Ennis and Jack in the film and simultaneously many people outside the text around the globe. In addition, the same-sex desire is a "deterritorialization" of the majoritarian sexuality — heterosexuality.

But Lee does not represent the same-sex desire as superficially corporeal but rather as "a delirium" oriented toward the deeper intimacy of spiritual implication and significance. In other words, he successfully creates a missing people who have cultivated an identification with Ennis and Jack's life story. In addition, the potential group of people (global audience) are becoming imperceptible in a state of delirium, which is the political function of literature according to Deleuze, as Daniel Smith points out:

When great artists such as Mallarmě, Rimbaud, Lee, Berg, or the Straubs evoke a people, what they find rather is that "the people are missing." For Deleuze, this implies a new conception of the "revolutionary" potential of literature. (xli)

Paradoxically, the missing people are namely the universal audience that includes many heterosexuals and 
anti-homosexuals (homophobes). The hybrid universal audience, be they homosexuals or heterosexuals, come to appreciate Lee's love story. The missing people (universal audience) that Lee has created thus enter into a state of delirium, thus become able to speak with and write [be] with Ennis and Jack in their spiritual world.

\section{Conclusion}

To conclude, Judith Buthler's deconstructive/postmodernist view of sex/gender/identity enables me to evaluate simultaneously both the positive and negative aspects of these two films; whereas Deleuze's literary aesthetics of minor literature offers me a subtle perspective on Ang Lee's extraordinary achievement in creating a minoritarian artistic work that exposes the complexity of human psyche, which constitutes the second part of this essay. Though the two parts of this essay may seem contradictory to each other, if viewed from different perspectives, the theories of Butler and Deleuze offer a brand new vision or insight into Ang Lee's experimental work. In BM, Lee presents a good example of minor writing (literature) that not only rewrites a popular short story by giving it new life or vision. This is a good example of how electronic mass media affect or transcend the silent literature (novels) by producing a good "representation" of the original story. More importantly, it seems to imply that in the so-called postmodern/electronic era, the audio-visual work made from electronic technology will take superiority over the silent literature. Moreover, Lee's painstaking work in "representing" the "unrepresentable" same-sex desire/love is becoming-imperceptible. The universal audience in their empathy rather than apathy thus becomes able to revalue or re-adjust their attitude toward homosexuality, enter into a state of delirium, speak with, write with Lee and the characters he creates

\section{References}

Bakhtin, M. (1981). Dialogic imagination: four essays. Trans. Caryl Emerson. Austin: U of Texas P.

Barry, P. (2002). Beginning theory. Manchester: Manchester UP.

Bogue, R. (2002). Gilles Deleuze and Felix Guattari. Postmodernism: The Key Figures. Eds. Hans Bertens and Joseph Natoli. Oxford: Blackwell.

- - -. (2003). Deleuze on literature. London: Routledge.

Brooke-Rose, C. (1991). Stories, theories and things. Cambridge: Cambridge UP.

Buchanan, I, and Marks J, eds. (2000). Deleuze and Literature. Edinburgh: Edinburgh UP.

Butler, J. (1999). Gender Trouble. New York: Routledge.

Colebrook, C. (2002). Gilles Deleuze. London: Routledge.

Connel, R. W. (2004). Gender. Oxford: Blackwell.

Deleuze, G., and Parnet, C. (1997). Dialogues. Trans. Hugh Tomlinson and Barbara Hobberjam. New York: Columbia UP.

Deleuze, G.. (1983). Nietzsche and philosophy. New York: Columbia UP.

- - - . (1997). Essays critical and clinical. Trans. Daniel W. Smith and Michael. A. Greco. Minneapolis: U of Minnesota

P.

Deleuze, G. and Guattari, G. (1984). Anti-Oedipus: capitalism and schizophrenia. London: Athlone.

- - -. (1986). Kafka: toward a minor literature. Trans. Dana Polan. Minneapolis: U of Minnesota P.

- - - (1992). A thousand plateaus: capitalism and schizophrenia. London: Athlone.

Holland, E. W. (1999). Deleuze and Guattari's Anti-Oedipus: Introduction to Schizoanaylsis. London: Routledge.

Hutcheon, L. (1980). A theory of parody: the teachings of twentieth-century art form. London: Methuen.

- - - (1988). A poetics of postmodernism: history, theory, fiction. New York: Routledge.

Lucy, N. (1997). Postmodern literary theory. Oxford: Blackwell.

Luo, G. S. (1997). Gilles Deleuze. Taipei: Dong-Da.

Lyotard, J-F. (1985). The postmodern condition: a report on knowledge. Minneapolis: Minnesota UP.

Marks, J. (1998). Gilles Deleuze: vitalism and multiplicity. London: Pluto.

McHale, B. (1987). Postmodernist fiction. London: Methuen.

Rose, M. (1993). Parody: Ancient, Modern, and Post-modern. Cambridge: Cambridge UP.

Walsh, M. R., ed. (1997). Women men, and gender: ongoing debates. New Haven: Yale UP.

Woods, T. (1999). Beginning postmodernism. Manchester: MaNcherster UP. 


\section{Notes}

Note 1. Here I borrow Butler's comment on Irigaray's argument about the feminine "sex" as "a point of linguistic absence, the impossibility of a grammatically denoted substance, and hence the point of view that exposes that substance as an abiding and foundation illusion of a masculinist discourse" (1999: 15).

Note 2. In Gender Trouble (pp. 9-11), Butler strongly attacks the impropriety of sex/gender distinction by marking the contingency and ambivalence of sex/gender. For Butler, either sex or gender is not given but culturally constructed as such.

Note 3. Essays Critical and Clinical (1993) is supposed to be Deleuze's final work and the only work that exclusively elaborates on literature, or to be more specific, a work that is "concerned with the delirium - the process of Life - that lies behind this invention, as well as the loss that occurs, the silence that follows, when this delirium becomes a clinical state" (quoted from the flap of the work published by University of Minnesota Press in 1997).

Note 4. In Essay Critical and Clinical, Deleuze illustrates his idea of (minor) literature by citing Proust's idea: "it [literature] opens up a kind of foreign language within language, which is neither another language nor a rediscovered patois, but a becoming-other of language, a minorization of this major language, a delirium that carries it off ... "(5) 